DOI: https://doi.org/10.32839/2304-5809/2021-3-91-58

УДК 347.965

Косяченко К.Е.

Дніпропетровський державний університет внутрішніх справ

\title{
АДВОКАТУРА ІІЇ ПРИЗНАЧЕННЯ ТА МІСЦЕ В ІНСТИТУТІ ГРОМАДЯНСЬКОГО СУСПІЛЬСТВА
}

Анотація. Особливим інститутом громадянського суспільства в Україні є інститут адвокатури. Про це свідчить імператив професійного захисту прав та законних інтересів осіб у суді, публічно-правовий статус досліджуваного інституту, надання державою права на отримання юридичної допомоги абсолютно всім фізичним і юридичним особам, також у даній статті розглядається питання призначення, ролі та місця адвокатури в інституті громадянського суспільства. Досліджуеться та висвітлюеться місце інституту адвокатури, фрундаментальним та головним призначенням якого - $є$ захист прав людини. Паралельно наголошуються питання діяльності органів адвокатури, а також важливі проблеми їх реформування. На сьогоднішній день розвиток цього інституту відбуваеться в рамках процесу модернізації правової системи - комплексу соціальних, економічних, правових, політичних, культурних та інтелектуальних трансформацій. Для інституту адвокатури України цей процес є дуже складним і суперечливим, оскільки в державі ще не сформувалися надійні механізми практичної реалізації громадянських прав і свобод.

Ключові слова: інститут адвокатури, забезпечення та захист прав і свобод людини і громадянина, адвокат, народ, громадянське суспільство.

Kosiachenko Kseniia

Dnipropetrovsk State University of Internal Affairs

\section{ADVOCACY ITS PURPOSE AND PLACE IN THE INSTITUTE OF CIVIL SOCIETY}

Summary. A special institution of civil society in Ukraine is the Institute of Advocacy. This is evidenced by the imperative of professional protection of the rights and legitimate interests of persons in court, the public legal status of the institution under investigation, the state's right to receive legal assistance to absolutely all individuals and legal entities society. The place of the bar institute, the fundamental and main purpose of which is the protection of human rights, is researched and covered. At the same time, the issues of the activity of the bar, as well as important problems of their reform are emphasized. Today, the development of this institution is part of the process of modernization of the legal system - a set of social, economic, legal, political, cultural and intellectual transformations. For the Bar Institute of Ukraine, this process is very complex and controversial, as the state has not yet formed reliable mechanisms for the practical implementation of civil rights and freedoms. According to other Ukrainian scholars, civil society is a society with developed economic, political, spiritual and other relationships and connections that interact with the state and operates based on democracy and rights. However, the Bar of Ukraine is not only an institution of civil society, but also a corporation, whose main duty is to provide protection interests of all civil society actors. This is evidenced by the need of civil society in this institution, which needs professional legal assistance professional lawyer, as most members of society are deprived of the opportunity to defend their own interests in conflicts with the state and others. Accordingly, the aspect that determines providing assistance to citizens in need solving problems with the government, confirms the social role of the bar.

Keywords: institute of advocacy, provision and protection of human and civil rights and freedoms, lawyer, people, civil society.

$\Pi$ остановка проблеми. Орієнтація розвиненості України в XXI ст. спрямована на ствердження фрундаменту правового громадянського суспільства. Як відомо, відмінною сферою, для найкращої розвиненості суспільства в його повсякденному житті є громадянське суспільство.

В громадянському суспільстві індивід, особа, людина є центральним аспектом цього суспільства, держава при здійсненні свого впливу (за допомогою права) має прислухатися до окремих інтересів та побажань кожного індивіда.

Особливим інститутом громадянського суспільства в Україні $е$ інститут адвокатури. I дійсно, сутність питання інституту адвокатури, а також роз'яснення призначення та місця адвоката та загалом адвокатури в громадянському суспільстві, е достатньо актуальним питанням на даному етапі розвиненості демократичного суспільства. Про це також засвідчуе обов'язковість професійного захисту індивіда в суді, надання державного права на отримання певної право- вої допомоги всім як фізичним так і юридичним особам, загальний правовий та публічний статус висвітлення та дослідження інституту.

Аналіз останніх досліджень і публікацій. Деякі проблеми обраної теми наукової статті зазначались та знайшли відображення у дослідженнях та працях видатних українських науковців, зокрема, В. Андреєвський, М. Андріянов, Ю. Бова, В. Богма, В. Козьмінних, В. Прилуцький, Д. Святоцький, В. Тацій, С. Титикало, С. Шемшученко та ін., а також зарубіжних вчених: Р. Кассен, М. Кіку, М. Кузінс, Ф. Рейган, Р. Сміт та ін.

Виділення не вирішених раніше частин загальної проблеми. Проте незважаючи на значну кількість публікацій, що присвячені інституту громадянського суспільства, науковщі досі комплексно не висвітлювали та не обгрунтовували питання адвокатури України та ï̈ призначення в інституті громадського суспільства в цілому. 
Мета статті. Головною метою цієї роботи e виконання певних завдань, а саме - зазначити зміст та сутність категорії «громадянське суспільство» за допомогою розкриття терміну «інститут адвокатури»; проаналізувати концептуальні положення адвокатури; дослідити функції адвокатури, та як вони зв'язані з громадянським суспільством, дослідити важливі питання адвокатури в громадянському суспільстві.

Виклад основного матеріалу. 3 постановки проблеми висвітлено те, що питання місця адвокатури в громадянському суспільстві е достатньо актуальним, з цього слідуе що в Україні на даному етапі залишаеться неоднозначним аспект практичної реалізації конституційних новаторств, саме правового розуміння адвокатури, iï ролі та призначення як у суспільстві, так і загалом держави. Згідно з Конституціею України ст. 131-2 в Україні є адвокатура, що має найважливішу значення задля забезпечення права на захист від обвинувачення та надання правової допомоги при вирішенні деяких справ у судах та інших державних органах.

Спробуемо зрозуміти та розібратися з аспектом адвокатури, для цього слід висвітлити головні концептуальні положення, що 望 стосуються. Якщо переглянути минулий Закон України «Про адвокатуру» (1993р.), то правовий інститут зазначався як певне професійне добровільно об'єднане громадське об'єднання, що спрямоване (згідно Конституції України) на захист прав та свобод, та представлення законних інтересів громадян України, осіб без громадянства, іноземних громадян, а також надання їм юридичної допомоги.

Згідно до ст. 2 Закону України «Про адвокатуру та адвокатську діяльність» (2012р.), адвокатура - це певний самоврядний недержавний інститут, забезпечуе захист представництва та надання різних видів правової допомоги на правовому рівні. Адвокатура вирішуе питання їі діяльності та організації в порядку, що встановлений Законом.

Якщо звернутися до аспектів міжнародного стандарту, треба зазначити «Основні принщипи, що стосуються ролі юристів», що прийняв восьмий конгрес $\mathrm{OOH} з$ приводу питань запобігання злочинності і правопорушників 27 серпня 1990 р. -7 вересня 1990 р. Серед принципів - перший передбачає, що будь яка людина мае законне право звернутися за правовою допомогою з приводу захисту своїх прав до юристів на всіх стадіях кримінального судочинства; за дев'ятнадцятим принципом - суд чи адміністративний орган, де визнаеться право на адвоката, не може відмовитися від прав юриста в обстоюванні в суді інтересів кліента.

Згідно 3 Міжнародним пактом про громадянські і політичні права (1966 р.), що ратифікували Указом Президії Верховної Ради Української РСР від 19 жовтня 1973 року, було висвітлено те, що держава має гарантувати всім і кожному, чиї свободи і права було порушено ефективний засіб юридичного захисту (стаття 2), можливість вільного вибору обвинуваченим захисника (п. 3 ст. 14). Конвенщію про захист прав людини і її основоположних свобод (1950р.), що закріплюе правом те, що кожний обвинувачений може як захищати себе особисто, так і з допомогою юридичного захисника, якого можна вибрати на власний розсуд (ст. 6).

Можна підвести підсумок того, що ні міжнародні акти ні закон не мають положень, що б зазначали, що адвокатура - це державний чи підпорядкований самій державі орган. Саме правова допомога в цивільних, кримінальних та адміністративних справах є саме функцією держави, що встановила українську адвокатуру як певне професійне громадське об’еднання. Зазначимо, що саме громадські організації (об'єднання) є основою громадянського організаційного суспільства.

Так чи дійсно адвокатура є інститутом громадянського суспільства? Своєрідним та особливим інститутом громадянського суспільства в Україні $\varepsilon$ інститут адвокатури. Тому важливе значення для комплексного розкриття самої сутності інституту адвокатури є визначення призначення та місця адвоката та адвокатури в громадянському суспільстві.

Для початку треба зазначити саму суть поняття «громадянське суспільство». Першим, хто докладно дослідив це поняття - був видатний німецький філолософ Георг В. Г. Гегель, що розглянув громадянське суспільство як певну диференціацію та розчленування, що є між державою та сім'єю [1, с. 228]. Мислитель вважав, що громадянське суспільство має свої коріння від суперечок між державою та сім'єю , а сама держава є поєднанням сім'ї і громадського суспільства.

«Термінологічний словник бібліотекара» надае таке визначення «Громадянське суспільство - це сфера самовияву загалом вільних індивідів і асоціацій, громадян та осіб, що утворилися добровільно. Ця сфера має захист з боку необхідних законів захищена від небажаного втручання в організацію діяльності, а також захист з боку певних органів влади. Отже, сама сутність терміну громадянське суспільство вбирае весь аспект неполітичних стосунків в суспільстві, серед яких - економічні, релігійні, духовно-моральні та національні і т.д. [10].

В наш час поняття громадського суспільства має місце в дуже різних значеннях. Найпоширенішим вважають поняття громадського суспільства як певного що загалом поєднують 3 важливою сферою приватних інтересів та потреб [3, с. 8].

Інститут адвокатури в багатьох розвинених державах базуеться на фундаментальних аспектах, таких як [8, с 22-25]:

1. Важливим професійним правилом адвоката $\epsilon-$ надання якісної юридичної допомоги всім бажаючим, не залежно від статусу.

2. Адвокати працюють в особливих відносинах 3 кліентом, що мають конфіденціальний характер та захищаються професійною етикою юристів та законодавством.

3. Адвокатська діяльність перебуває під певним контролюючим тиском професіональних адвокатських організацій, що мають важливу роль в правовій допомозі дотримання певних стандартів та професійних норм. Прийняті восьмим Конгресом ООН в 1990 рощі «Основні положення про роль адвокатів» [5] передбачають також дисщиплінарний суд над адвокатами, що порушили будь які правила професійної етики юриста.

4. Адвокатура є найважливішим інститутом громадянського суспільства, що має за мету охо- 
рону приватних осіб при юридичних судових дебатах. Вільний, самостійний та незалежний таким повинен бути адвокат, що може практикувати як з колегами так і індивідуально.

5. Держава забезпечуе фінансування для соціально незабезпечених та незахищених верств населення з приводу профресіональної юридичної допомоги.

6. Згідно до згаданого документу ООН [5] уряд зобов'язаний «надавати всім адвокатам рівну можливість виконувати всі їх профресійні обов'язки без залякування та будь-яких перешкод, турбування і недоречного втручання в їх діяльність».

В 1864 рощі, після судової реформи, що закріпила права осіб на захист своїх прав в суді, роз починається масштабний розвиток самостійного правового інституту адвокатури в Україні. Повіреними - в ті часи саме так називали громадян, що працювали адвокатами. Мало місце дві категорії адвокатів: приватні повірені (18-річні особи, що склали іспити в окружному суді та мали свідоцтво про офріційне право вести судові справи) і присяжні повірені (особи, що мали вищу юридичну освіту і 5 років стажу роботи в суді) [9, с. 21]. Далі в адвокатурі з'являються певні зміни, які утворили основні аспекти і положення адвокатури (важлива система визначення гонорару, свобода адвокатської профресії і т.д.).

Новим етапом в історіографії адвокатури є 20 роки $\mathrm{XX}$ століття, коли відбувся стрімкий перехід в колективну форму, в містах почали з'являтися багато правових юридичних консультацій. 1970 рік відкрили тернистий шлях редрормування адвокатури, відбувалося стрімке дослідження методики надання безоплатної правової допомоги всім верствам населення. Діяльність адвокатури була на низькому рівні (принципи демократії були порушені, права людини і громадянина не дотримувалися, змагальне судочинство було взагалі відсутне. Незважаючи на негативні аспекти, в 1970 році відбулися позитивні зміни в статусі адвокатів, зокрема утворилися правові консультащії з будь-яких юридичних питань, було встановлена їх діяльність [3].

Після проголошення незалежності України 24 серпня 1991 року призначення та чільне місце адвокатури було помітно визначене. Незалежність адвокатури є дуже вагомою умовою охорони та захисту прав людини та громадянина. Підтвердженням можна вважати Закон України, прийнятий 19 грудня 1992 року «Про адвокатуру", де було вказано, що адвокатура це добровільне профресійне громадське об'єднання, що спрямоване на якісний захист свобод та прав осіб. Адвокати представляють законні інтереси і права громадян, осіб без громадянства, юридичних осіб, іноземних громадян надавати їм якісну правову допомогу [6].

Звертаючи увагу на досить неквапливий розвиток адвокатської діяльності в Україні слід зазначити, що інститут адвокатури має дуже важливе місце в громадянську суспільстві.

Так, основними фрункціями $є-$ надання якісної правової допомоги як в судах, так і в інших державних органах, право на охорону від обвинувачення.

Правозахисний аспект адвокатури має певну двоєдиність, що базується в основному на поді- лі фрункцій корпоративні (приватні) і суспільні (публічні). Питання визначення функцій адвокатури в працях вчених та дослідників є мало висвітленим.

Обловацька Н. О. висвітлюе те, що адвокатська діяльність для втілення своеї мети та завдань повинна спрямовуватися на досягнення певних соціокультурних цінностей, що і $є$ фрункціями, серед яких: 1) дисциплінарна - має за мету застосувати до порушника юридичних норм (відповідача) - певних покарань у відшкодуванні витрат за послуги адвоката позивача; 2) відновлююча фрункція - $є$ головною фрункцією в діяльності адвокатів, базується на відтворенні прав, які було порушено з приводу інтересів громадян; 3) превентивна - фрункція, що застерігає суб'єктів права про ситуацію, що може сприяти утворенню певних правових наслідків; 4) фрункція охорони - захист кліентів в суді, права та свободи яких було порушено [4, с. 47].

Прилуцький С.В. в свою чергу говорить про те, що адвокатура - має одне з важливіших місць в правовому механізмі правосуддя, $е$ важливим членом правового процесу має також вагому функцію за суспільним контролем в цьому аспекті. Науковець зазначає - «Самостійна та принципова правова позиція окремого адвоката в будьякій справі є підгрунтям для повністю незалежної думки адвокатського об'єднання 3 приводу державного режиму законності. Це допоможе утворити активну та правильну юридичну позицію адвокатської діяльності щодо редормованих процесів юридичної системи держави» [7, с. 12].

Українська адвокатура являє собою не лише інститут соціального суспільства, вона також $\epsilon$ корпорацією, за мету якої лежить встановлення захисту прав і свобод громадян України. Це вказує на те, що суспільство має потребу у цьому інституті, для того щоб отримувати фрахову правову допомогу з боку кваліфікованих юристів, тому що великий відсоток громадян України не має змоги самостійно відстоювати свої права у конфлікті з державою. Таким чином той елемент, що вказуе на надання правової підтримки суб'єктам права, що потребують щього у вирішенні протиріч 3 державою і вказуе на соціальну фрункцію адвокатури.

Хотілось також зазначити, що адвокатура потребуе значного розширення своїх фрункщій. Загалом залишається відомими той фракт, що адвокатська діяльність виконуе фрункцію щодо надання якісної юридичної правової допомоги кожній потребуючій особі, але адвокатура також виконуе і інші функщї, серед яких: злагодженість стосунків держави та суспільства (медіативна фрункція), розуміючи та вшановуючи законодавство, що визначає та корегує діяльність адвокатів (нормотворча фрункція), поширення правових основ в маси (просвітницька фрункція), підводячи підсумок в законопроектних висновках, що стосуються діяльності та праці адвокатів (законодавча ініціатива).

Висновки i пропозиції. Проаналізувавши суть адвокатури та адвокатської діяльності, можна виділити певні статуси адвокатури, серед яких: - адвокатура як об'єднання адвокатів; - адвокатура - важлива профресія та професійний обов'язок; - адвокатура - захист прав людини в суді. 
У визнанні ролі та значимості інституту адвокатури, як складової правозахисних інститутів країни, фрундаментальним е саме те що цей інститут водночас існує, як невіддільна частина механізму держави, а саме відправлення правосуддя, що є запорукою суспільної довіри органам судової влади, це дуже важливо для результативної та ефрективної роботи суду, також для конституційного контролю за законодавчою та виконавчою владою у питанні дотримання прав і свобод людини закріплені у конституціі. Фіксування на законодавчому рівні діяльності адвокатури як правозахисної діяльності, відображається у Конституції, та дозволяе характеризувати інститут адвокатури відповідно, як конституційний інститут, що захищає не тільки права и свободи членів суспільства яким це потрібно, так наголошують певні вчені правники, а також забезпечення їх, це охоплюе гарантування, захист та охорону.

Хотілося б також зазначити певні особливості української адвокатури, як інституту громадянського суспільства, серед яких адвокатура це:

a) соціально-державне об'єднання громадянського суспільства, що націлене на охорону та захист свобод та прав особи людини і громадянина;

б) утворений аспект самостійної правозахисної ланки;

в) публічно-правовий інститут Українського громадянського суспільства;

г) якщо подивитися $з$ одного боку, то головним завданням інституту адвокатури громадського суспільства є захист свобод та прав осіб, але з іншого охорона всіх інтересів громадянського суспільства (а також його інститутів) також відіграє важливу роль; г) саме адвокатура є інститутом громадянського суспільства, і саме на їі розвиненість впливає аспект правової культури нашого населення, а також правової волі держави.

Щоб інститут української адвокатури прогресував та ставав кращим в умовах сьогоденної держави з розвиненою правовою системою, потрібно:

1) зробити правову допомогу більш доступною для всіх соціальних прошарків;

2) підвищувати рівень профресійної правової допомоги;

3) надавати можливість адвокатам виконувати свої обов'язки безперешкодно;

4) форомувати вірне розуміння стосовно ролі адвокатури у країні та її користі для населення;

5) надати адвокатурі цілковитої незалежності;

6) підвищити рівень довіри серед суспільства до роботи адвокатури.

Взагалі адвокатура є головним та невідчужуваним, нерозривним інститутом громадянського суспільства. Тільки якщо адвокатура буде розглядатися науковцями як повністю незалежний інститут громадянського суспільства - допоможе утворити неймовірний, злагоджений механізм в реалізації головної закріпленої фрункції, з приводу надання повної, якісної, юридично підібраної профресійної правової допомоги для задоволення інтересів суспільства та кожної особи

Отже, адвокатура України є публічно-правовим інститутом, що має за мету захист та представлення інтересів народу в цілому та його окремих індивідів. Відповідно інститут функціонуе для того щоб відстоювати права, свободи, суспільні блага людини і громадянина.

\section{Список літератури:}

1. Гегель Ф.В. Философия права : пер. с немец. Ред. и сост. Д.А. Керимов, В.С. Нерсесянц; пер. М.И. Левина, Б.Г. Столпнер. Москва : Мысль, 1990. С. 524.

2. Козьміних А.В. Адвокатура як інститут громадянського суспільства в сучасній науці. Актуальні проблели політики. Вип. 36. Одеса, 2009.

3. Козьміних А.В. Роль інституту адвокатури в реалізації правозахисної функції громадянського суспільства : автореф. дис. на здоб. наук. ступ. канд. політ. наук : спец. 23.00.02. Одеса, 2008. 18 с.

4. Обловацька Н.О. Поняття адвокатської діяльності в Україні та Росї̈ Адвокат. 2011. № 11. С. $45-48$.

5. Основні положення про роль адвокатів: ООН; Положення, Міжнародний документ від 01.08.1990. URL: http://zakon5.rada.gov.ua/laws/show/995_835

6. Про адвокатуру : Закон України від 19 грудня 1992 р. № 2887-ХІІ. Відомості Верховної Ради України. 1993. № 9. Ст. 1.

7. Прилуцький С.В. Судова влада в умовах фрормування громадянського суспільства та правової держави в Україні : дис. ... доктора юрид. наук : 12.00.10. Київ : Київ. нац. ун-т ім. Тараса Шевченка, 2013. 433 с.

8. Резник Г. Закон об адвокатуре как жертва конфликта интересов. Российская юстиция. 1998. № 3. С. $22-25$.

9. Святоцький О.Д., Михеенко М.М. Адвокатура України. Київ : Видавничий дім «Ін Юре», 1997. 224 с.

10. Терминологический словарь библиотекаря по социально-экономической тематике. URL: http://www.nlr.ru/ cat/edict/EcoDict/index1.htm

\section{References:}

1. Hegel F.V. (1990) Philosophy of Law: lane. with a German. Ed. and comp. D.A. Kerimov, V. S. Nersesianc; WE. Levina, B.G. Stolpner. Moscow: Mysl, 524 p.

2. Kozminykh A.V. (2009) Advocacy as an institution of civil society in modern science. Actual problems of politics, vol. 36. Odessa.

3. Kozminykh A.V. (2008) The role of the bar in the implementation of the human rights function of civil society: Science: special. 23.00.02. Odessa, $18 \mathrm{p}$.

4. Oblovatskaya N.O. (2011) The concept of advocacy in Ukraine and Russia Lawyer, no. 11, pp. 45-48.

5. Basic provisions on the role of lawyers: UN; Regulations, International document dated 01.08.1990. Available at: http://zakon5.rada.gov.ua/laws/show/995_835

6. On the Bar: Law of Ukraine of December 19, 1992 № 2887-XII Information of the Verkhovna Rada of Ukraine. 1993 . № 9.

7. Prylutsky S.V. (2013) Judiciary in the formation of civil society and the rule of law in Ukraine: dis. ... Doctor of Laws. Science: 12.00.10. Kyiv: Kyiv. Univ. Taras Shevchenko, 433 p.

8. Reznik G. (1998) Law on Advocacy as a Victim of Conflict of Interest Russian Justice, no. 3, pp. 22-25.

9. Sviatotsky O.D., Mikheenko M.M. (1997) Advocacy of Ukraine. Kyiv: In Yure Publishing House, 224 p.

10. Terminological dictionary of librarians on socio-economic issues. Available at: http://www.nlr.ru/cat/edict/EcoDict/ index1.htm 